\title{
Harvester Butterfly, Feniseca tarquinius (Fabricius) (Insecta: Lepidoptera: Lycaenidae: Melitinae) ${ }^{1}$
}

Donald W. Hall, Marc Minno, and Jerry F. Butler²

\section{Introduction}

The larvae of the small, uncommon harvester butterfly, Feniseca tarquinius (Fabricius), are the only strictly carnivorous butterfly caterpillars in the United States.

\section{Distribution}

Found in swampy areas and woodlands, particularly near water, from southern Canada south to central Florida and central Texas. Highly localized with adults generally remaining in close proximity to woolly aphid hosts.

\section{Description}

Adults: The wings are orange on the interior, bordered with black on the dorsal surface and burnt-orange with darker spots edged with white on the ventral surface.

Eggs: The eggs are greenish-white and spherical with faint sculpturing.

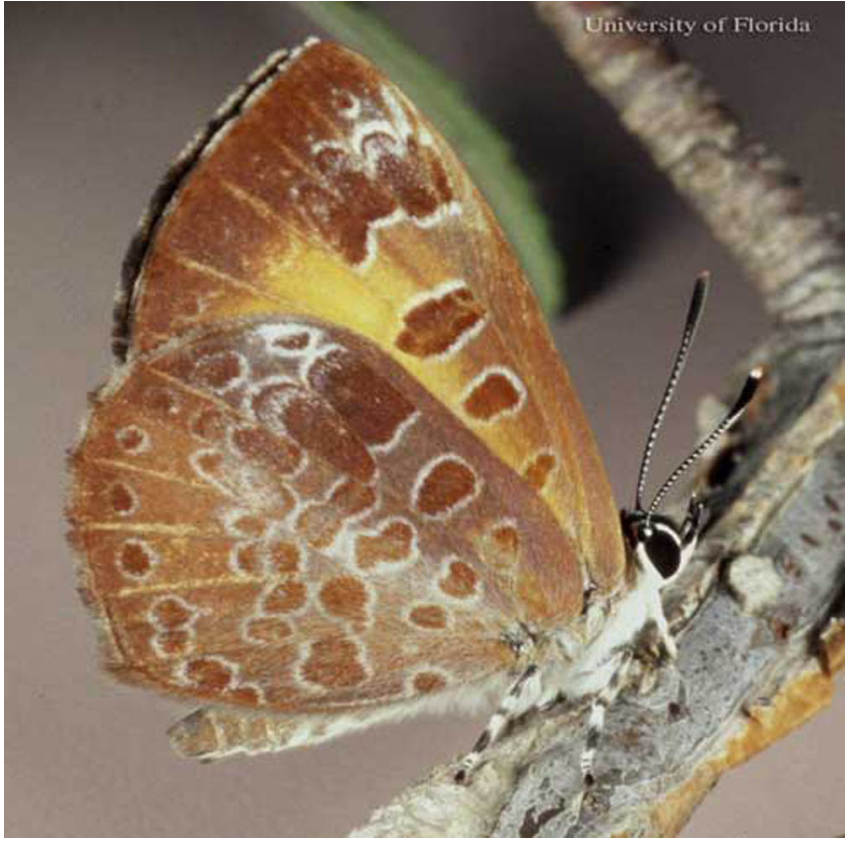

Figure 1. Adult harvester butterfly, Feniseca tarquinius (Fabricius). Credits: D.W. Hall, University of Florida

Larvae: The larvae are small (to $1.9 \mathrm{~cm}$ in length) and slug-like, brightly patterned with gray, yellow and white, and covered with bristly hairs; the pattern is often obscured with the white wax produced by the prey (Minno et al 2005).

1. This document is EENY-404 (IN727), one of a series of Featured Creatures from the Entomology and Nematology Department, Florida Cooperative Extension Service, Institute of Food and Agricultural Sciences, University of Florida. Published: April 2007. This document is also available on Featured Creatures Website at http://creatures.ifas.ufl.edu. Please visit the EDIS Website at http://edis.ifas.ufl.edu.

2. Donald W. Hall and Jerry F. Butler, Department of Entomology and Nematology, University of Florida, Gainesville, FL and Marc Minno, St. John's River Water Management District.

The Institute of Food and Agricultural Sciences (IFAS) is an Equal Opportunity Institution authorized to provide research, educational information and other services only to individuals and institutions that function with non-discrimination with respect to race, creed, color, religion, age, disability, sex, sexual orientation, marital status, national origin, political opinions or affiliations. U.S. Department of Agriculture, Cooperative Extension Service, University of Florida, IFAS, Florida A. \& M. University Cooperative Extension Program, and Boards of County Commissioners Cooperating. Larry Arrington, Dean 


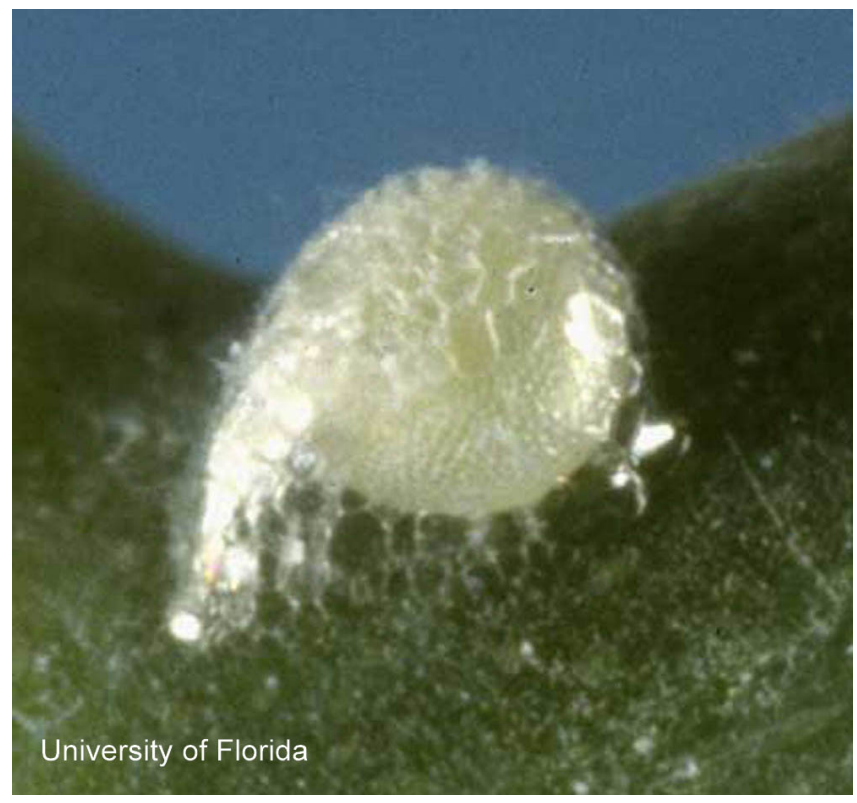

Figure 2. Egg of the harvester butterfly, Feniseca tarquinius (Fabricius). Credits: D.W. Hall, University of Florida

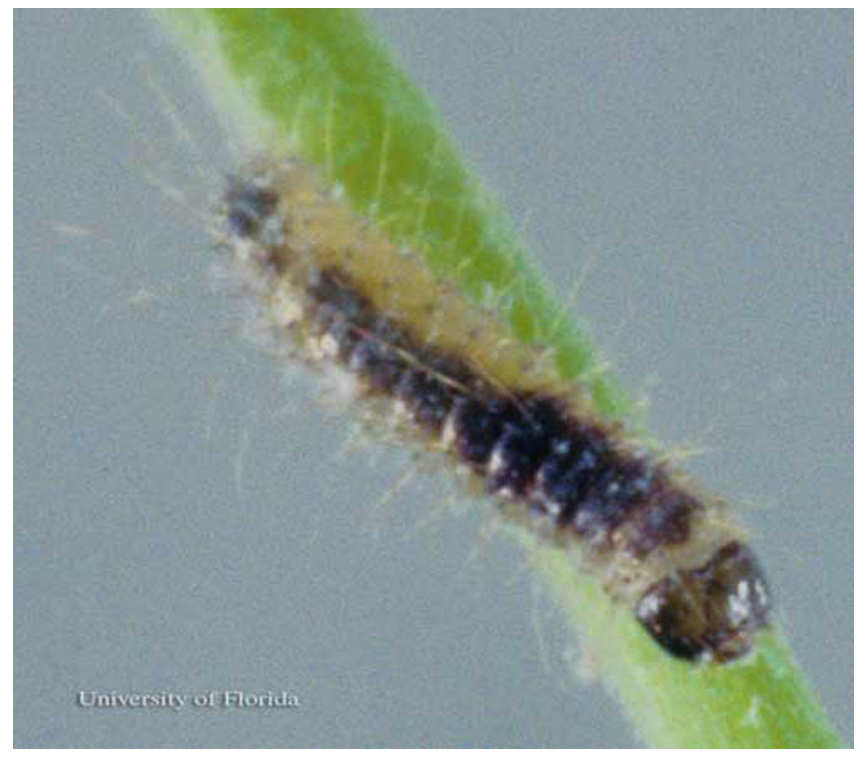

Figure 3. First instar larva of the harvester butterfly, Feniseca tarquinius (Fabricius), full of woolly maple aphid blood. Credits: Jerry F. Butler, University of Florida

Pupae: The pupae are off-white and have a pattern that resembles the face of a lizard or monkey (Krizek 1995).

\section{Life Cycle and Biology}

There are two to three generations in Canada and the northern U.S. and from three to six generations in the southern U.S.. Eggs are laid singly on leaves or stems near colonies of the woolly aphid prey.

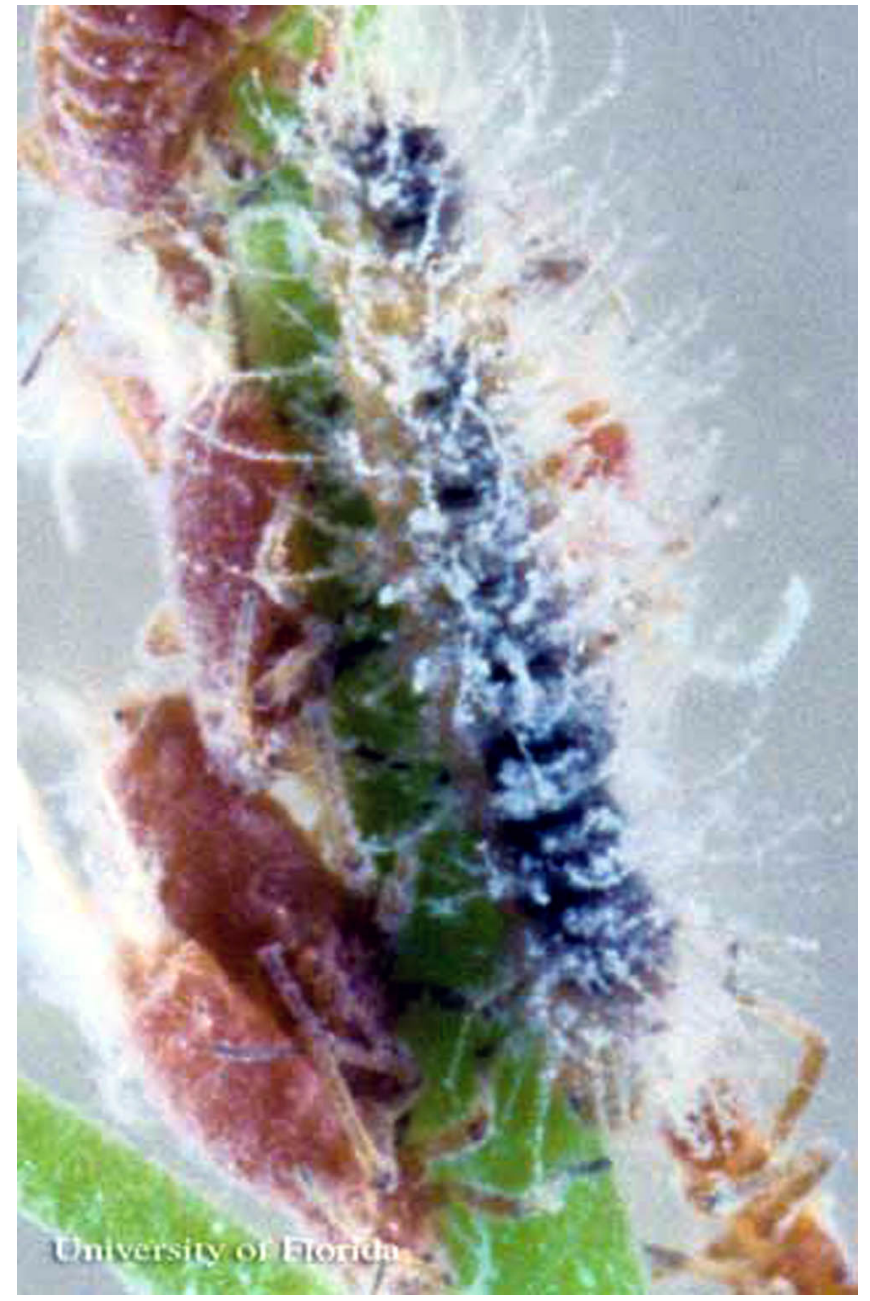

Figure 4. Early instar larva of the harvester butterfly, Feniseca tarquinius (Fabricius), partially covered with wax from woolly maple aphid prey. Credits: Jerry F. Butler, University of Florida

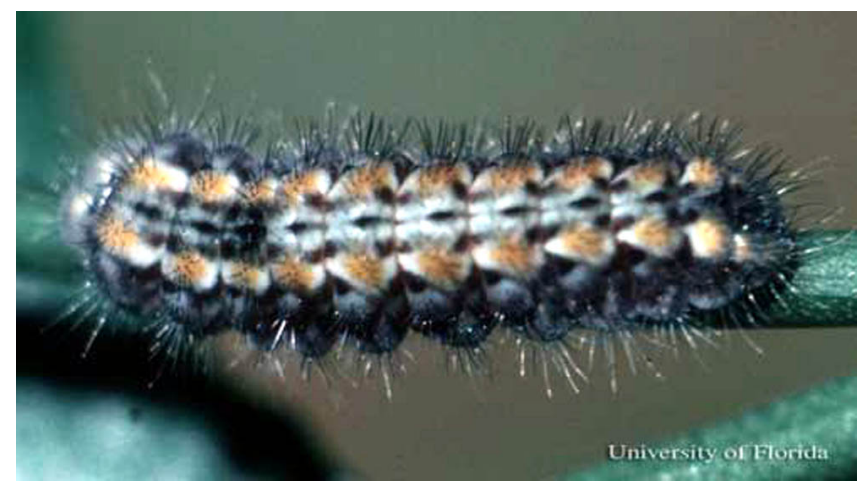

Figure 5. Full-grown larva of the harvester butterfly, Feniseca tarquinius (Fabricius). Credits: Jerry F. Butler, University of Florida

Caterpillars are present from June in the North and from February through early November in Florida. 


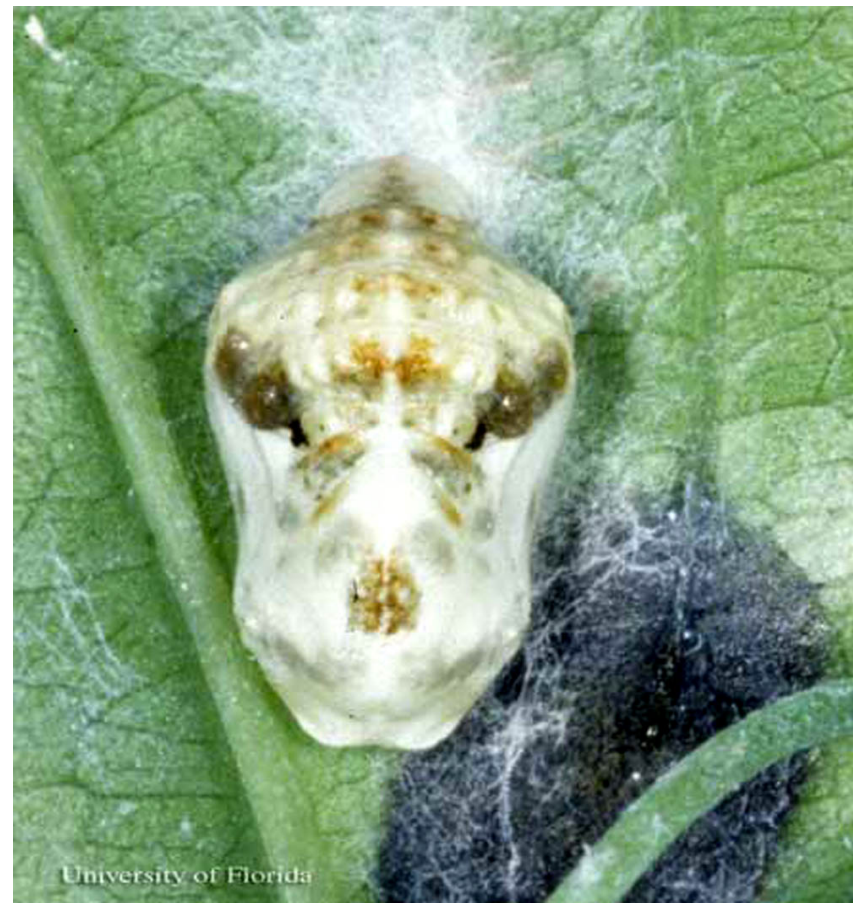

Figure 6. Pupa of the harvester butterfly, Feniseca tarquinius (Fabricius). Credits: Jerry F. Butler, University of Florida

Overwintering is by the pupal (chrysalis) stage (Allen 1997).

Because the harvester caterpillar is carnivorous, development proceeds very rapidly, with the larval stage being completed in as little as eight days. Harvester larvae have only four larval instars. Most other butterflies have five (Layberry et al. 2002). First instar larvae may restrain their larger aphid prey with silk prior to attacking them (Hall, unpublished observations).

Some harvester caterpillars cover themselves with the remains of woolly aphids they have eaten. The carcasses are tied on with silk, perhaps to protect the caterpillars from predacious ants (that tend and protect the aphids) and other natural enemies. Harvester caterpillars are less likely to conceal themselves when their woolly aphid prey is tended by Camponotus and Formica ants (Youngsteadt and Devries 2005).

Lohman et al. (2006) reported that the caterpillars share part of the cuticular hydrocarbon profile of the aphids and may be protected from the aphid-attending ants and protected by the ants from other predators by this chemical mimicry. Although harvester larvae lack the secretory and call-production organs of other ant-attended lycaenids (Youngsteadt and Devries 2005), they are sometimes attended by ants (Wagner 2005). Interestingly, harvester pupae do have well-developed stridulatory organs (Douglas 1986). The function of these organs in the pupae is not known.

The proboscis of harvester adults is very short, and they do not feed on floral nectar. Instead, they feed on aphid honeydew, dung, sap, and also sip from mud (Scott 1986). Because the adults are small in size, spend most of their time in the locality of their aphid prey, have an erratic flight, and do not feed at flowers, they are not commonly seen. Therefore, they are probably perceived as being more uncommon than they actually are (Wagner 2005).

\section{Hosts}

Harvester larvae are predacious on woolly aphids of at least five genera: Meliarhizophagus, Neoprociphilus, Pemphigus, Prociphilus, and Schizoneura (Iftner et al. 1992, Minno et al. 2005, Scott 1986, Opler and Krizek 1984); and possibly on other Homoptera.

The common prey species in Florida are woolly maple aphids, Neoprociphilus aceris (Monell), that suck sap from earleaf greenbriar (Smilax auriculata Walter), saw greenbriar (Smilax bona-nox L.), cat greenbrier (Smilax glauca Walter), and bristly greenbrier (Smilax tamnoides L.), in the smilax family (Smilacaceae); as well as woolly alder aphids, Prociphilus tesselatus (Fitch) (formerly Paraprociphilus tesselatus Fitch) that feed on hazel alder (Alnus serrulata (Aiton)Willd.), in the birch family (Betulaceae) (Minno et al 2005).

\section{Selected References}

Allen TJ. 1997. The Butterflies of West Virginia and their Caterpillars. University of Pittsburgh Press. Pittsburgh, Pennsylvania. 388 pp.

Douglas MM. 1986. The Lives of Butterflies. The University of Michigan Press. Ann Arbor, Michigan. $241 \mathrm{pp}$. 


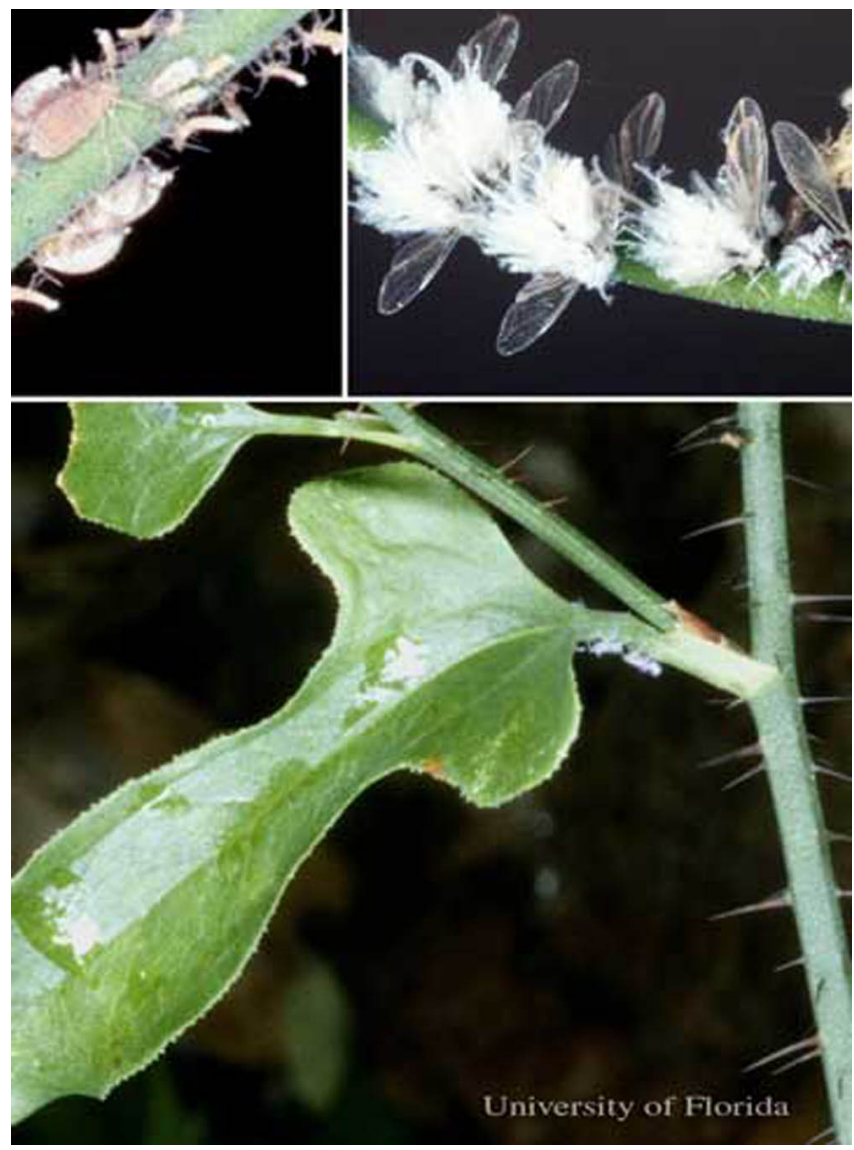

Figure 7. Bristly greenbriar (bottom), Smilax tamnoides L.; and nymphal (top-left) and adult (top-right) woolly maple aphids, Neoprociphilus aceris (Monell). Credits: D.W. Hall, University of Florida

Iftner DC, Shuey JA, Calhoun JV. 1992. Butterflies and Skippers of Ohio. Ohio Biological Survey Bulletin. New Series Bol. 9 No. 1. College of Biological Sciences. The Ohio State University. Columbus, Ohio. 212 pp.

Krizek GO. 1995. Butterfly pupae mimicking mammalian (or vertebrate) faces. Holarctic Lepidoptera 2: 74.

Layberry RA, Hall PW, Lafontaine JD. 1998 The Butterflies of Canada. University of Toronto Press. $376 \mathrm{pp}$.

Lohman DJ, Liao Q, Pierce NE. 2006 Convergence of chemical mimicry in a guild of aphid predators. Ecological Entomology 31: 41-51.

Minno MC, Butler JF, Hall DW. 2005. Florida Butterfly Caterpillars and their Host Plants. University Press of Florida. Gainesville, Florida. 341 pp.

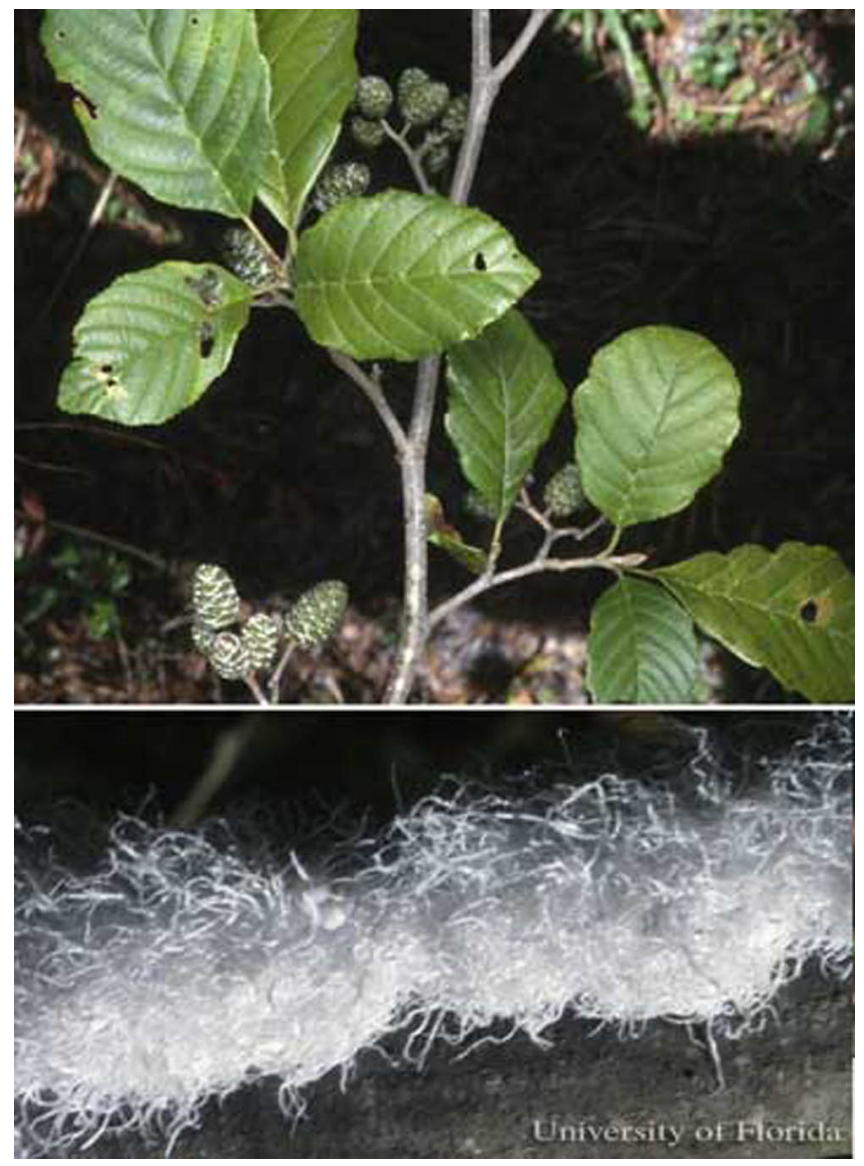

Figure 8. Hazel alder (top), Alnus serrulata (Aiton)Willd. (Betulaceae); and adult woolly alder aphids (bottom), Prociphilus tesselatus (Fitch) (formerly Paraprociphilus tesselatus Fitch) . Credits: D.W. Hall, University of Florida

Opler PA, Krizek GO. 1984. Butterflies East of the Great Plains. The Johns Hopkins University Press. Baltimore, Maryland. 294 pp.

Scott JA. 1986. The Butterflies of North America: A Natural History and Field Guide. Stanford University Press. Stanford, California. 583 pp.

Wagner DL. 2005. Caterpillars of Eastern North America. Princeton University Press. Princeton, New Jersey. 512 pp.

Youngsteadt E, Devries PJ. 2005. The effects of ants on the entomophagous butterfly caterpillar Feniseca tarquinius, and the putative role of chemical camouflage in the Feniseca-Ant interaction. Journal of Chemical Ecology 31: 2091-2109. 